Tomoki Nishiyama MD PhD, Kazuo Hanaoka MD PhD

\title{
Gas embolism during hysteroscopy
}

Purpose: Gas embolism during hysteroscopy is rare but sometimes fatal. A fatal case of gas embolism during diagnostic hysteroscopy using carbon dioxide $\left(\mathrm{CO}_{2}\right)$ is presented.

Clinical features: A $68 \mathrm{yr}$ old woman was admitted for treatment of myoma and cancer of the uterus. Hysteroscopy using $\mathrm{CO}_{2}$ was performed without monitoring or anesthesia on the ward. At the end of the examination, just after the hysteroscope was removed, she developed tonic convulsions, lost consciousness, and her pulse was impalpable. Cardiac massage was started, anesthesiologists were called and the trachea was intubated. She was transferred to the intensive care unit with continuous cardiac massage. Cardiac resuscitation was successful. A central venous line was inserted into the right ventricle under echocardiography in an attempt to aspirate gas with the patient in the Trendelenberg position, but the aspiration failed. Positive end expiratory pressure and heparin for emboli, midazolam for brain protection, and catecholamines were administered. Fifteen hours after resuscitation, the pupils were enlarged and she died $25 \mathrm{hr}$ after resuscitation.

Conclusion: Gas embolism is a rare complication of hysteroscopy. The procedure should be performed with monitoring of blood pressure, heart rate, oxygen saturation and end-tidal $\mathrm{CO}_{2}$ concentration.

Objectif : L'embolie gazeuse est rare mais parfois fatale pendant l'hystéroscopie. On présente ici un cas malheureux d'embolie gazeuse pendant l'hystéroscopie diagnostique avec du gaz carbonique $\left(\mathrm{CO}_{2}\right)$.

Eléments cliniques : Une femme de 68 ans a été admise pour le traitement d'un myome et d'un cancer de l'utérus. On a procédé à une hystéroscopie avec $\mathrm{CO}_{2}$ sans monitorage ou anesthésie dans la salle. À la fin de l'examen, dès qu'on a enlevé l'hystéroscope, elle a subi des convulsions toniques, une perte de conscience et son pouls était impalpable. On a commencé le massage cardiaque, appelé les anesthésiologistes et intubé la trachée. La patiente a été transférée à l'unité des soins intensifs pendant qu'on poursuivait le massage. La réanimation cardiaque a été un succès. La patiente étant en position de Trendelenberg, un cathéter veineux central a été inséré sous échocardiographie dans l'espoir d'aspirer les gaz, mais l'aspiration a échoué. On a administré une pression positive et expiratoire et de l'héparine pour contrer l'embolie, du midazolam pour protéger le cerveau et des catécholamines. Quinze heures après la réanimation, les pupilles étaient dilatées et la patiente est décédée $25 \mathrm{~h}$ après la réanimation.

Conclusion : L'embolie gazeuse est une complication rare de l'hystéroscopie. L'intervention devrait être réalisée sous monitorage de la pression sanguine, de la fréquence cardiaque, de la saturation en oxygène et de la concentration en $\mathrm{CO}_{2}$ de fin d'expiration.

From the Department of Anesthesiology, The University of Tokyo, Faculty of Medicine.

Address correspondence to: Tomoki Nishiyama MD PhD, Department of Anesthesiology, The University of Tokyo, Faculty of Medicine, 7 -

3-1 Hongo, Bunkyo-ku, Tokyo, 113-8655 Japan. Phone: 81-3-5800-8668; Fax: 81-3-5800-8938

Accepted for publication January 12, 1999 
$\mathrm{H}$ YSTEROSCOPY has been widely used as both a diagnostic and a therapeutic tool for more than a decade. As media, highmolecular weight dextran, dextrose in water, or carbon dioxide $\left(\mathrm{CO}_{2}\right)$ are widely used. In our institution, $\mathrm{CO}_{2}$ is used routinely to obtain a wider field of view. Although the procedure has been considered to be safe, gas $\left(\mathrm{CO}_{2}\right.$ or air) embolism, is a rare complication and may be fatal. ${ }^{1}$ We report a lethal case of gas embolism which occurred during hysteroscopy using $\mathrm{CO}_{2}$ without anesthesia or monitoring.

\section{Case report}

A 68 yr old woman $(142 \mathrm{~cm}, 45 \mathrm{~kg})$ was admitted for treatment of myoma and cancer of the uterus. She had no history of allergy. Examination at admission showed a slight increase of serum lactate dehydrogenase concentration (639 IU. $\mathrm{L}^{-1}$, normal upper limit: $378 \mathrm{IU} \cdot \mathrm{L}^{-1}$ ) and sporadic supraventricular extrasystoles in electrocardiogram (ECG). There were no other abnormalities on hematological examination, liver and renal function, or chest X-ray.

Hysteroscopy was performed for diagnosis in the treatment room of the ward without anesthesia. She was placed in the supine lithotomy position. Glucose solution, $10 \%$, was administered via a peripheral venous line. No monitors were used. Carbon dioxide was used as an insufflating gas and the examination was completed uneventfully. However, immediately after the hysteroscope was removed, she developed tonic convulsions, lost consciousness and her pulse was impalpable. Cardiac massage was started and anesthesiologists were called. The trachea was intubated and she was transported to the intensive care unit with continuous cardiac massage injecting epinephrine (total $1 \mathrm{mg}$ ) and with artificial ventilation. Resuscitation was successful using electrical defibrillation. The ECG showed antero-septal infarction and $5-15 \mu \mathrm{g} \cdot \mathrm{kg}^{-1} \cdot \mathrm{min}^{-1}$ dopamine, 7.5 - $15 \mu \mathrm{g} \cdot \mathrm{kg}^{-1} \cdot \mathrm{min}^{-1}$ dobutamine and norepinephrine (total $26.5 \mathrm{mg}$ ) were given to keep systolic blood pressure $>100 \mathrm{mmHg}$. Blood gas data were $\mathrm{pH}$ 7.136, $\mathrm{PaO}_{2} 66 \mathrm{mmHg}\left(\mathrm{F}_{\mathrm{I}} \mathrm{O}_{2}=1.0\right), \mathrm{PaCO}_{2} 86.3$ $\mathrm{mmHg}$, base excess $-15.7 \mathrm{mM} \cdot \mathrm{L}^{-1}$ during resuscitation. In parallel with resuscitation, a $70 \mathrm{~cm} 19 \mathrm{G}$ catheter was inserted through the brachial vein into the right ventricle under echocardiography. Attempts to aspirate gas through the catheter under echocardiography with the patient in the Trendelenburg position failed, although many bubbles were detected in the right ventricle. Positive end expiratory pressure $\left(12 \mathrm{cmH}_{2} \mathrm{O}\right)$ was used. Heparin was given for the prevention of thrombotic embolism and midazolam was given for brain protection. Instead of the intensive therapy and transient improvement of blood gas data $\left(\mathrm{pH}: 7.472, \mathrm{PaO}_{2}: 170\right.$ $\mathrm{mmHg}, \mathrm{PaCO}_{2}: 33 \mathrm{mmHg}$, base excess: $1.2 \mathrm{mM} \cdot \mathrm{L}^{-1}$, $\left.\mathrm{F}_{1} \mathrm{O}_{2}=0.5\right), 15 \mathrm{hr}$ after resuscitation, pupils were enlarged, and the light reflex disappeared. She died 25 $\mathrm{hr}$ after resuscitation.

\section{Discussion}

This case of diagnostic hysteroscopy was fatal because of lack of monitoring and observers. Diagnostic hysteroscopy usually requires little or no cervical dilatation and constitutes a small risk. In a survey of 1000 out-patient diagnostic hysteroscopies, no gas embolism was seen. ${ }^{2}$ All reported cases of gas embolism have occurred during hysteroscopy with some operative procedures. ${ }^{3-7}$ This case is a rare case of embolism that occurred at the end of the hysteroscopy without any operative procedures.

We could not determine whether the bubbles seen with echocardiography were $\mathrm{CO}_{2}$ or air in this case. From animal studies, the increased solubility of $\mathrm{CO}_{2}$ is expected to give a wide margin of safety compared with the use of air. ${ }^{8}$ The injection of $200 \mathrm{ml}$ air at 70 to 100 $\mathrm{ml} \cdot \mathrm{sec}^{-1}$ would be fatal in humans. ${ }^{9}$ In the present case, many bubbles were detected by echocardiography even after transportation to the intensive care unit, which suggests a lot of gas entered the circulation.

The earliest signs of gas embolism are a sudden decrease in end tidal $\mathrm{CO}_{2}$ concentration, bradycardia, decrease in oxygen saturation, or a mill-wheel murmur by precordial auscultation. ${ }^{3}$ However, the characteristic mill-wheel murmur is a late sign of cardiovascular collapse. Although central venous pressure, pulmonary arterial pressure, and esophageal echocardiography are useful to detect gas embolism, these are all invasive. Therefore, end tidal $\mathrm{CO}_{2}$ concentration, heart rate (or ECG), oxygen saturation may be the common choice for detecting gas embolism during hysteroscopy.

Corson et al. ${ }^{1}$ reported five deaths from gas embolism due to late resuscitation while early intervention saved the patient in another report. ${ }^{5}$ In our case, resuscitation was delayed because the procedure was done in the ward without monitoring. Hyperbaric oxygen therapy is another therapeutic option, ${ }^{4}$ but was not available in our hospital. Thus, we attempted to aspirate the gas under echocardiography through a catheter in the right ventricle, but the attempt failed.

For out-patient hysteroscopy, Cooper et al. ${ }^{2}$ used local anesthesia in $31.4 \%$ of patients, while Mencaglia $e t$ $a l .^{10}$ performed the procedure without anesthesia. In 1000 out-patient diagnostic hysteroscopies, the procedure failed in 23 patients because of pain or anxiety. ${ }^{2}$ In considering the pain and the risk of gas embolism, hysteroscopy should be performed under anesthesia with 
monitoring of blood pressure, heart rate, oxygen saturation and end tidal $\mathrm{CO}_{2}$ concentration.

In conclusion, a fatal case of gas embolism during diagnostic hysteroscopy without monitoring is reported. The procedure should be performed with the appropriate monitoring and preferably under anesthesia.

\section{References}

1 Corson SL, Brooks PG, Soderstrom RM. Gynecologic endoscopic gas embolism. Fertil Steril 1996; 65: 529-33.

2 Cooper MJW, Broadbent JAM, Molnár BG, Richardson $R$, Magos $A L$. A series of 1000 consecutive out-patient diagnostic hysteroscopies. J Obstet Gynaecol 1995; 21: 503-7.

3 Brooks $P G$. Venous air embolism during operative hysteroscopy. J Am Assoc Gynecol Laparosc 1997; 4: 399-402.

4 Nachum Z, Kol S, Adir $\Upsilon$, Melamed $\Upsilon$. Massive air embolism - a possible cause of death after operative hysteroscopy using a $32 \%$ dextran -70 pump. Fertil Steril 1992; 58: 836-8.

5 Behnia R, Holley HS, Milad M. Successful early intervention in air embolism during hysteroscopy. J Clin Anesth 1997; 9: 248-50.

6 Perry PM, Baughman VL. A complication of hysteroscopy: air embolism. Anesthesiology 1990; 73 : 546-7.

7 Diakun TA. Carbon dioxide embolism: successful resuscitation with cardiopulmonary bypass. Anesthesiology 1991; 74: 1151-3.

8 Corson SL, Hoffman JJ, Jackowski J, Chapman GA. Cardiopulmonary effects of direct venous $\mathrm{CO}_{2}$ insufflation in ewes. A model for $\mathrm{CO}_{2}$ hysteroscopy. J Reprod Med 1988; 33: 440-4.

9 Kizer KW, Goodman PC. Radiographic manifestations of venous air embolism. Radiology 1982; 144: 35-9.

10 Taylor PJ, Hamou JE. Clinical perspectives.

Hysteroscopy. J Reprod Med 1983; 28: 359-89. 